\title{
CHARACTERISTICS OF A DOUBLY-FED ASYNCHRONOUS GENERATOR APPLIED IN WIND TURBINES ${ }^{1}$
}

\author{
Žarko Milkič ${ }^{2}$, Aleksandar Čukarič ${ }^{3}$, Saša Štatkič ${ }^{4}$, Goran Maksimovićc ${ }^{5}$
}

\begin{abstract}
Summary
A mathematical model of a doubly-fed asynchronous generator is defined in the paper, using spatial vector theory, in relation to the reference axis associated with the stator. Expressions for characteristic quantities are derived, and operational characteristics for the torque, active and reactive power, power factor, and efficiency are plotted, from which generator operation is analysed at different rotational speeds. Based on this, possibilities and advantages of using doubly-fed asynchronous generators in wind turbines, for obtaining electrical energy from wind energy, are deduced.
\end{abstract}

Key words: renewable sources, wind turbines, sustainable development.

JEL: $Q 1, Q 19$

\section{Introduction}

For decades, electrical power was being obtained from conventional sources: coal, oil, gas, nuclear fuel. However, this production is accompanied by some undesirable effects, among which environmental pollution is the most severe, and even alarming. On the other hand, timescale for the recovery of fossil fuel is too long, and the reserves of it are being gradually exhausted.

1 Paper is a part of research within the project no. TR 33016 - Research, development and implementation of programs and procedures Energy efficiency of electric drives, 2011-2018, financed by the Ministry of Education, Science and Technological Development of the Republic of Serbia. Project period: 2011-2018.

2 Žarko Milkić, Ph.D., Associate Professor, University of Pristina, Faculty of Technical Sciences, Knjaza Milosa 7, 38220 Kosovska Mitrovica, Serbia, Phone: +381 28425321 , E-mail: zarkomilkic@yahoo.com

3 Aleksandar Čukarić, Ph.D., Associate Professor, University of Pristina, Faculty of Technical Sciences, Knjaza Milosa 7, 38220 Kosovska Mitrovica, Serbia, Phone: +381 28425321 , E-mail: acacu58@gmail.com

4 Saša Štatkić, Ph.D., Associate Professor, University of Pristina, Faculty of Technical Sciences, Knjaza Milosa 7, 38220 Kosovska Mitrovica, Serbia, Phone: +381 28425 321, E-mail: $\underline{\text { sasa.statkic@pr.ac.rs }}$

5 Goran Maksimović, Ph.D., Associate Professor, University of Pristina, Faculty of Agriculture, 38219 Lešak, Serbia, Phone: +381 2888 261, E-mail: goran.maksimovic@pr.ac.rs

EP 2018 (65) 1 (229-241) 
It is for these reasons that exploitation of alternative or renewable sources for electric energy production began at the end of the last century. Among these, wind stands out as the most important, since it has immense capacity and is cost-free, ecologically clean, and unrestricted in time.

In certain developed countries, already more than one quarter of electric power comes from wind power stations, and this share tends to grow rapidly (Petersson, 2005).

Renewable energy potential in Serbia, excluding large hydro power plants, is estimated to $25 \%$ of the primary power consumption (Radojević et al., 2009). Next to the biomass, there is a number of different renewable energy sources, such as wind energy, small hydro power plant, geothermal energy and the solar energy. Even though the biomass energy source currently has the largest potential, it is not sustainable as wind and solar energy, which cannot be exhausted (Milanović, Cvijanović, 2009).

The energy-consumer requirements in Serbia are highest during the winter. The maximum availability of the wind energy typically occurs during the winter, while the solar energy peaks occur in the summer (Gburčik, Mastilović, Vučinić, 2013).

The amount of solar energy received over the vegetation period is also important for calculating the potential for biomass production. According to Project Report (Gburčik et al., 2013), daily amounts of solar energy during the vegetation period ranges from $4.9 \mathrm{kWh} /$ $\mathrm{m}^{2}$ on the west, to $5.7 \mathrm{kWh} / \mathrm{m}^{2}$ on the southeast of Serbia.

Considering the geographical position of Serbia and the climatic conditions, the most suitable model for supplying agricultural property from renewable sources for their sustainable development is a hybrid model, which consists of wind generators and solar panels.

A region with fertile agricultural land and with locations potentially suitable for the construction of wind generators in Serbia is located north of the Danube River, i.e. wider region of the territory where wind kosava blows. This area covers about $2000 \mathrm{~km}^{2}$ and is suitable for the construction of wind generators (Mikičić et al., 2006).

The objective of this article is to present a brief assessment of the variable-speed wind turbine with doubly-fed induction generator (DFIG) because of its advantages, such as small power converter rating and the ability to control the output power.

Choice of an appropriate electric generator is crucial in the process of converting wind energy into electric power, due to the stochastic nature of the wind. The essence of this conversion lies in making the wind turbine efficiency as large as possible. This means that at every wind speed maximum electric power of desired quality should be obtained (Vukić et al., 2006).

The use of standard generators comes with a lot of problems. The most acceptable solution is found in using a doubly-fed asynchronous generator, (Figure 1.), especially for high power, because it allows the rotating speed of the wind turbine to change efficiently within a wide range. The speed can change to become either lower or higher than the synchronous speed (Adjoudj et al., 2011). 
The stator is connected directly to the grid, while the rotor circuit contains the voltage and frequency energy converter, which also enables the electric current to flow in both directions (Krause, 2013).

Mathematical model of a doubly-fed asynchronous generator is defined by using spatial vector theory (Justo et al., 2014; Mohammadi et al., 2014). Usually asynchronous machines are modelled using the well-known "T-form" equivalent circuit with self and mutual inductances. Expressions for all characteristic quantities are derived from general voltage and flux equations. Operational characteristics are plotted as functions of both the load and the slip angle. Conclusions about the applicability of doubly-fed asynchronous generators in wind power stations and the advantages they offer are drawn from the analysis of specific quantities (Quang, Dittrich, 2015; Leonhard, 2001).

Figure 1. Schematic representation of a doubly-fed asynchronous generator.

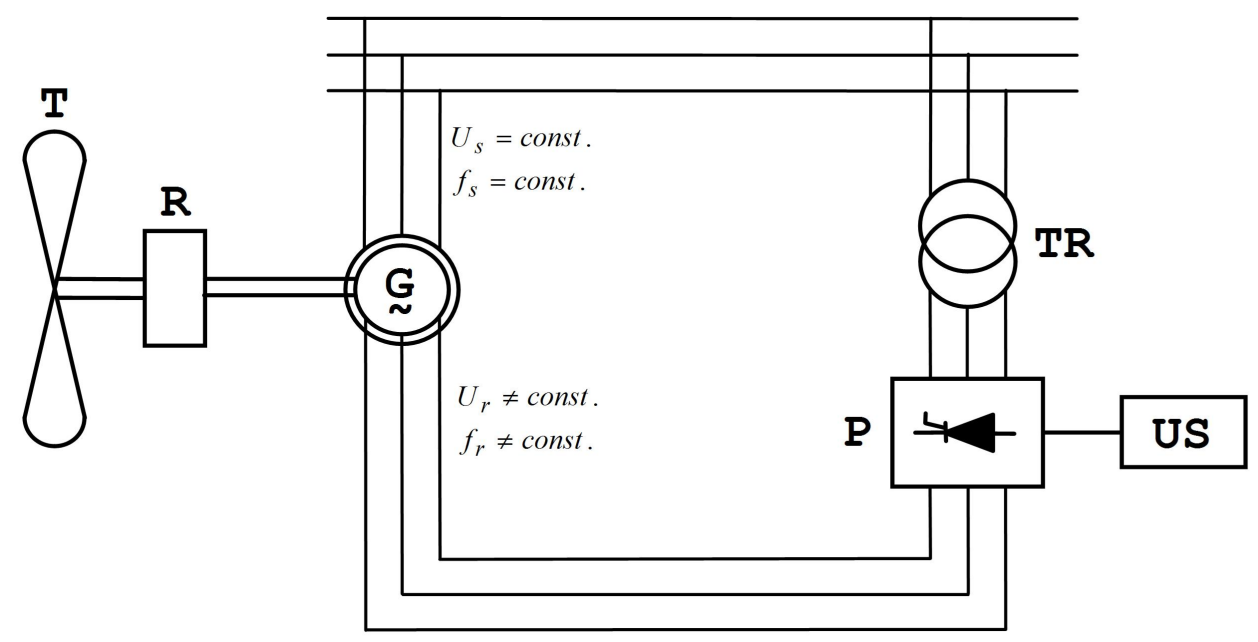

\section{Mathematical model for a doubly fed asynchronous generator}

Since the operation of the doubly-fed asynchronous generator is considered in synchronous regime (controlled frequency is set independently), it is most convenient to use a mathematical model obtained from spatial vector theory (Elhassan et al., 2014; Padrón et al., 2010; Boardman et al., 2003), defined relative to the reference axis associated with the stator, the speed of which equals the synchronous speed $\omega_{\mathrm{s}}$.

Speed regulation is possible both above and under the synchronous speed, as well as in both directions (Milkić et al., 2014). Angular velocity is defined by:

$$
n=\frac{60}{\Pi}\left(f_{1} \mp f_{2}\right)
$$

The mathematical model can be represented by the following set of complex equations (Milkić et al., 2014; Soens et al., 2003):

EP 2018 (65) 1 (229-241) 


$$
\begin{aligned}
& \mathbf{U}_{s}=-\mathbf{I}_{s} R_{s}-d \boldsymbol{\psi}_{s} / d t-j \omega_{s} \boldsymbol{\Psi}_{s} \\
& \mathbf{U}_{r}=-\mathbf{I}_{r} R_{r}-d \boldsymbol{\Psi}_{r} / d t-j\left(\omega_{s}-\omega\right) \boldsymbol{\Psi}_{r} \\
& \boldsymbol{\Psi}_{s}=\mathbf{I}_{s} L_{s}+\mathbf{I}_{r} L_{m} \\
& \boldsymbol{\Psi}_{r}=\mathbf{I}_{s} L_{m}+\mathbf{I}_{r} L_{r}
\end{aligned}
$$

Using the differentiating operator $\mathrm{p}$ voltage and flux equations, observed in the said reference frame and expressed in relative units, are:

$$
\begin{aligned}
& \mathbf{u}_{s}=-\mathbf{i}_{s} r_{s}-(p+j) \boldsymbol{\Psi}_{s} \\
& \mathbf{u}_{r}=-\mathbf{i}_{r} r_{r}-(p+j s) \boldsymbol{\Psi}_{r} \\
& \boldsymbol{\psi}_{s}=\mathbf{i}_{s} x_{s}+\mathbf{i}_{r} x_{m} \\
& \boldsymbol{\psi}_{r}=\mathbf{i}_{s} x_{m}+\mathbf{i}_{r} x_{r}
\end{aligned}
$$

where $x_{s}$ and $x_{r}$ are total inductive reactances per phase of the stator and the rotor, respectively while the slip is defined as:

$$
s=f_{r} / f_{s}=\left(\omega_{s}-\omega\right) / \omega_{s}
$$

Stationary operation is considered, so plugging $p=0$ into (6) and (7) yields:

$$
\begin{aligned}
& \mathbf{u}_{s}=-\mathbf{i}_{s} r_{s}-j \boldsymbol{\psi}_{s} \\
& \mathbf{u}_{r}=-\mathbf{i}_{r} r_{r}-j s \boldsymbol{\psi}_{r} \\
& \boldsymbol{\psi}_{s}=\mathbf{i}_{s} x_{s}+\mathbf{i}_{r} x_{m} \\
& \boldsymbol{\psi}_{r}=\mathbf{i}_{s} x_{m}+\mathbf{i}_{r} x_{r}
\end{aligned}
$$

The stator voltage vector $\mathbf{u}_{s}$ is taken to define the positive direction of the real axis, while the rotor voltage vector $\mathbf{u}_{r}$ leads by an angle $\vartheta$. Hence:

$$
\mathbf{u}_{s}=u_{s} \cdot e^{j 0^{\circ}}, \quad \mathbf{u}_{r}=u_{r} \cdot e^{j \vartheta}
$$

where $\vartheta$ is the phase angle between stator and rotor voltage vectors. Vector diagram for the doubly-fed asynchronous generator (Muller et al., 2002) in the synchronous operating mode shows that the phase angle between stator and rotor voltage vectors $\vartheta$ and the angle between the stator axis and the stator voltage vector $\delta$ (called the load angle, in line with synchronous machine terminology) are related as (Figure 2.): 


$$
\delta=\vartheta-\alpha
$$

where the angle $\alpha$ is given by:

$$
\alpha=\operatorname{arctg} \frac{s r_{s} x_{r}-r_{r} x_{s}}{r_{s} r_{r}+s x_{s} x_{r}-s x_{m}^{2}}
$$

Figure 2. Phasor diagram for a doubly fed asynchronous generator

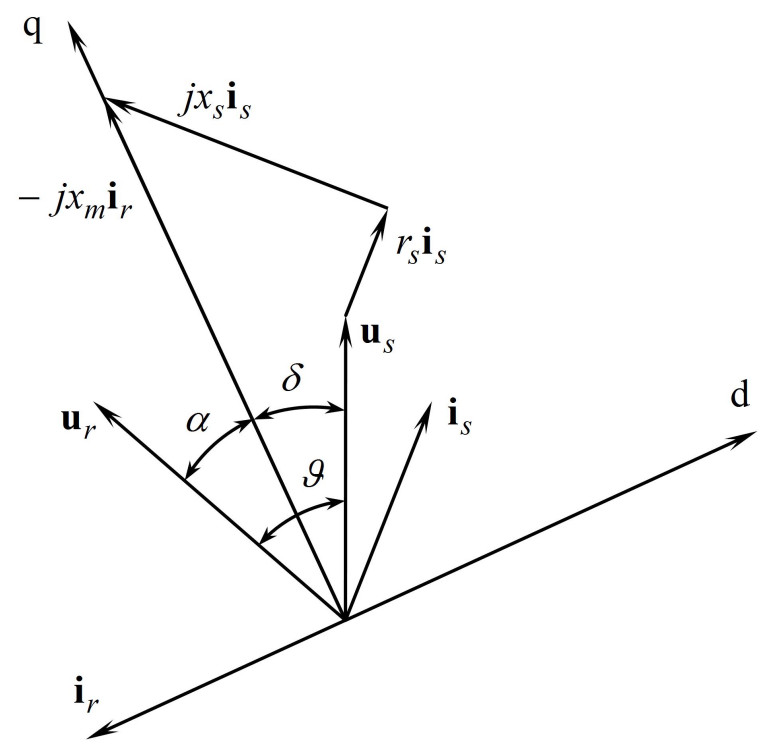

\section{Operational characteristics}

Solving the voltage and flux equations (11), (12), (13) and (14), taking into account assumptions (15), (16) and (17), yields expressions for characteristic quantities of a doubly-fed asynchronous generator in the synchronous operating regime. Operational characteristics are plotted for an asynchronous generator with $200 \mathrm{kVA}$ nominal power, for which the parameters from the equivalent scheme, expressed in relative units, are: $r_{s}=0.022$ p.u., $r_{r}=0.026$ p.u., $x_{s y}=0.14$ p.u., $x_{r y}=0.14$ p.u. and $x_{m}=3.4$ p.u.. Voltage and frequency of the stator remain constant, while rotor quantities change, with a constant ratio of rotor voltage and frequency $u_{r} / f_{r}=$ const. Since $\mathrm{s}=f_{r} / f_{s}$, in relative units $u_{r}=\mathrm{s}$. 


\section{Electromagnetic torque}

General expression for the electromagnetic torque of a doubly-fed asynchronous generator is:

$$
\begin{aligned}
& m_{e m}=\frac{u_{s}^{2}}{k_{1}^{2}+k_{2}^{2}}\left(s r_{r} x_{m}^{2}-u^{2} r_{s} x_{m}^{2}\right)+ \\
& +\frac{u_{s}^{2}}{k_{1}^{2}+k_{2}^{2}} u x_{m}\left[-\left(r_{s} r_{r}+s x_{s} x_{r}-s x_{m}^{2}\right) \sin \vartheta+\left(s r_{s} x_{r}-r_{r} x_{s}\right) \cos \vartheta\right]
\end{aligned}
$$

Figure 3. a) Dependence $m=f(s)$; b) Dependence $m=f(\delta)$.

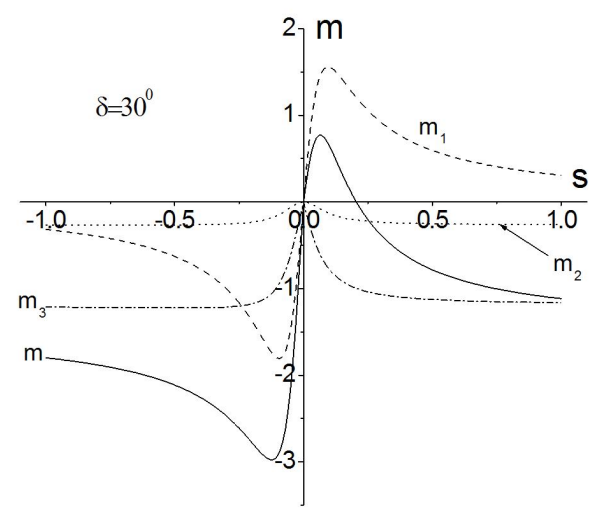

a)

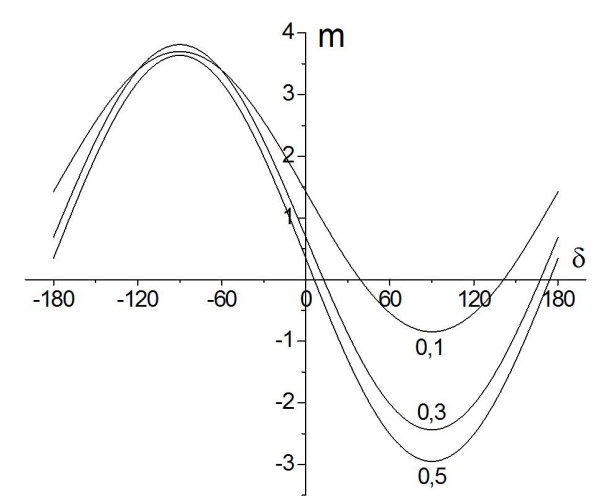

b)

Expressed as a function of the load angle the electromagnetic torque is:

$$
m_{e m}=\frac{u_{s}^{2}}{k_{1}^{2}+k_{2}^{2}}\left(s r_{r} x_{m}^{2}-u^{2} r_{s} x_{m}^{2}+u x_{m} \sqrt{a^{2}+b^{2}} \cdot \sin \delta\right)=m_{1}+m_{2}+m_{3}
$$

where: $k_{1}=r_{s} r_{r}-s\left(x_{s} x_{r}-x_{m}^{2}\right), k_{2}=s r_{s} x_{r}+r_{r} x_{s}$, and $u=u_{r} / u_{s}$.

The torque consists of three components. The first two $\left(m_{1}\right)$ and $\left(m_{2}\right)$ are asynchronous, while the third $\left(m_{3}\right)$ is a synchronous component that corresponds to the angular torque of the synchronous generator to whose rotor voltage $u_{r}$ is applied. Fig. 3.a) shows the three components of the torque, as well as the resultant torque, versus the slip angle, for a load angle of $\delta=30^{\circ}$. Owing to the presence of the synchronous component, the resultant torque is at its maximum for $\delta=\pi / 2$ regardless of the slip, as shown in Fig. 3.b). 


\section{Stator and rotor powers}

Final expressions for stator and rotor active power are, respectively:

$$
\begin{aligned}
& p_{s}=\frac{u_{s}^{2}}{k_{1}^{2}+k_{2}^{2}}\left[\left(r_{r} k_{1}+s x_{r} k_{2}\right)-u x_{m}\left(k_{2} \cos \vartheta+k_{1} \sin \vartheta\right)\right] \\
& p_{r}=\frac{u_{s}^{2}}{k_{1}^{2}+k_{2}^{2}}\left[u s x_{m}\left(k_{1} \sin \vartheta-k_{2} \cos \vartheta\right)+u^{2}\left(r_{s} k_{1}+x_{s} k_{2}\right)\right]
\end{aligned}
$$

Dependences of active power (equations (20) and (21)) on the load and the slip angle are presented in Figs. 4. a)...b) for both stator and rotor, while reactive power curves (based on expressions (22) and (23)) are shown in Figs. 5. a)... b).

Figure 4. a) Dependence $p=f(\delta)$; b) Dependence $p=f(s)$.

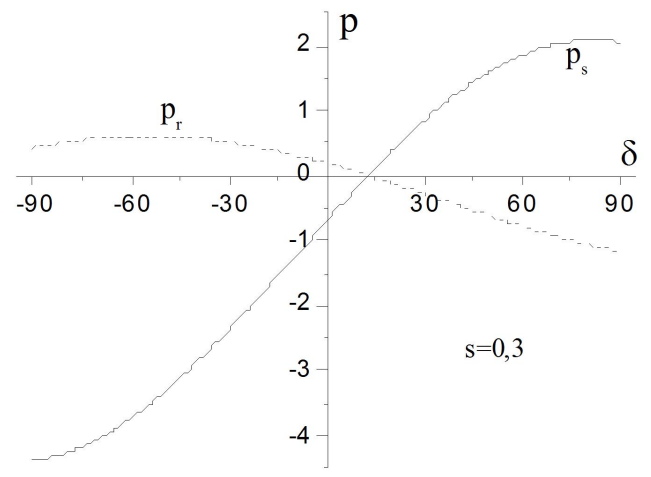

a)

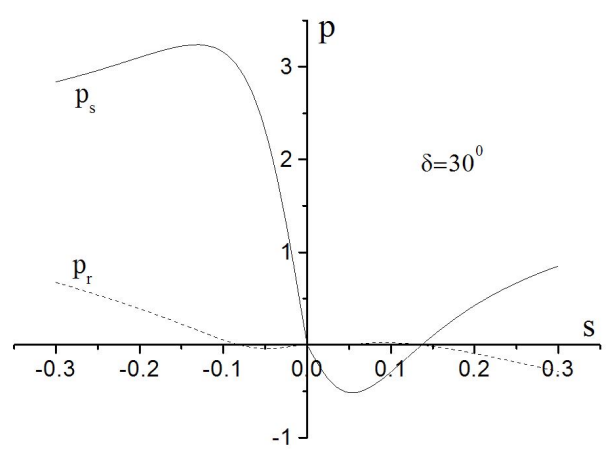

b)

The equations for stator and rotor reactive power are:

$$
\begin{aligned}
& q_{s}=-\frac{u_{s}^{2}}{k_{1}^{2}+k_{2}^{2}}\left[\left(s x_{r} k_{1}-r_{r} k_{2}\right)-u x_{m}\left(k_{1} \cos \vartheta-k_{2} \sin \vartheta\right)\right] \\
& q_{r}=-\frac{u_{s}^{2}}{k_{1}^{2}+k_{2}^{2}}\left[u^{2}\left(x_{s} k_{1}-r_{s} k_{2}\right)-u s x_{m}\left(k_{1} \cos \vartheta+k_{2} \sin \vartheta\right)\right]
\end{aligned}
$$


Figure 5. a) Dependence $q=f(\delta)$; b) Dependence $q=f(s)$.

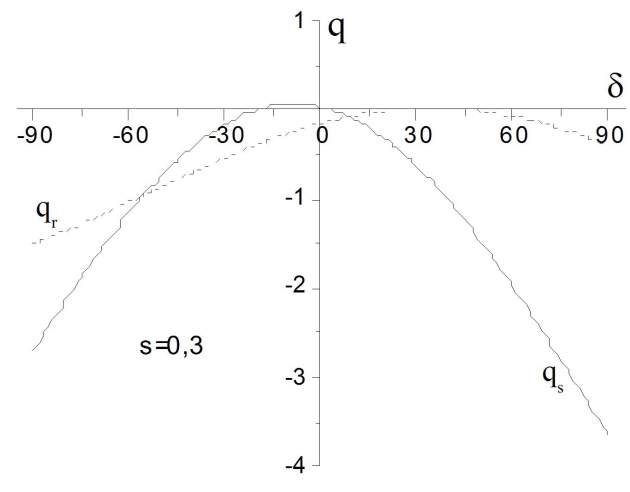

a)

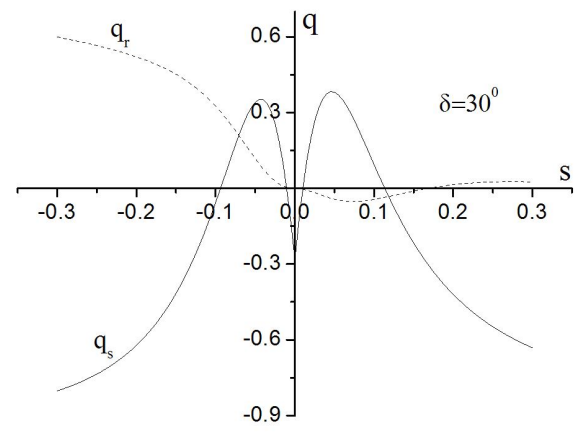

b)

Analysis of characteristics shown in the figures provides insight into a specific power flow in the doubly-fed asynchronous generator. When the generator works with speeds that are lower than the synchronous speed (positive slip), active power is transmitted to the load at stator side, while rotor consumes active power from the grid. However, in the supersynchronous regime $(\mathrm{s}<0)$, both the stator and the rotor supply the grid with active power. This is a great advantage, because double feeding can lead to an operation mode with a power higher than nominal, since total active power equals the sum of active powers from both the stator and the rotor.

\section{Stator and rotor power factors}

In order to meet specific needs of electric power systems, a doubly-fed asynchronous generator, intended for producing active power, in some cases also has to produce reactive power, i.e. it has to work with a desired stator power factor. Figs. 6. a)...b) show the dependences of the power factor on the load angle and slip, respectively. It can be inferred from these graphs that by setting an appropriate rotor voltage change, constant power factor operation can be achieved.

$$
\begin{aligned}
& \cos \varphi_{s}=\frac{\left(r_{r} k_{1}+s x_{r} k_{2}\right)-u x_{m}\left(k_{2} \cos \vartheta+k_{1} \sin \vartheta\right)}{\sqrt{\left(k_{1}^{2}+k_{2}^{2}\right)\left[\left(r_{r}^{2}+s^{2} x_{r}^{2}\right)+u^{2} x_{m}^{2}-2 u x_{m}\left(s x_{r} \cos \vartheta+r_{r} \sin \vartheta\right)\right]}} \\
& \cos \varphi_{r}=\frac{u\left(r_{s} k_{1}+x_{s} k_{2}\right)-s x_{m}\left(k_{2} \cos \vartheta-k_{1} \sin \vartheta\right)}{\sqrt{\left(k_{1}^{2}+k_{2}^{2}\right)\left[s^{2} x_{m}^{2}+u^{2}\left(r_{s}^{2}+x_{s}^{2}\right)-2 u s x_{m}\left(x_{s} \cos \vartheta-r_{s} \sin \vartheta\right)\right]}}
\end{aligned}
$$


Figure 6. a) Dependence $\cos \varphi=f(\delta)$; b) Dependence $\cos \varphi=f(s)$.

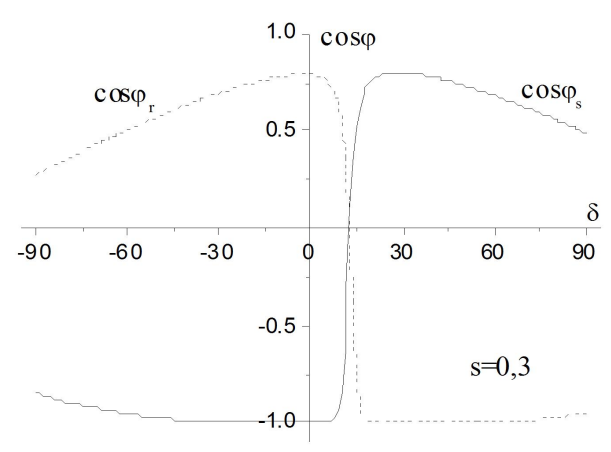

a)

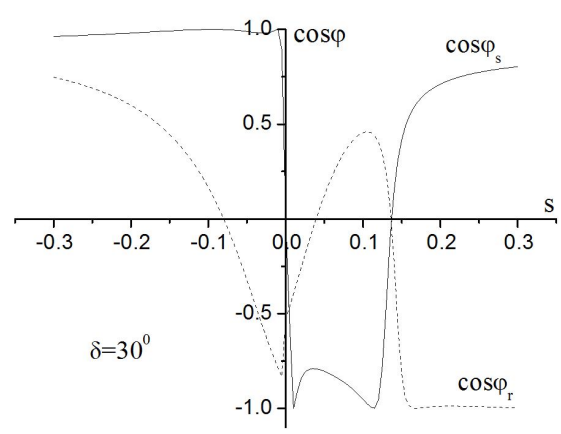

b)

\section{Efficiency}

The main indicator of how economic the operation of a doubly-fed asynchronous generator is, comes from analyzing the characteristics of its efficiency, Figs. 7. a)... b), obtained from expression:

$$
\eta=1-\frac{r_{s} i_{s}^{2}+p_{F e_{s}}+r_{r} i_{r}^{2}+s p_{H k_{r}}+s^{2} p_{F k_{r}}+p_{f v_{n}}(1-s)^{\frac{3}{2}}}{m_{e m}(1-s)+p_{f v_{n}}(1-s)^{\frac{3}{2}}}
$$

Comparison with characteristics that correspond to standard operation reveals a slight decrease of efficiency, caused by the presence of higher harmonics in stator and rotor currents, which results in the appearance of additional losses and additional torques. An appropriate change of the applied rotor voltage can insure operation with minimal losses.

Figure 7. a) Dependence $\eta=f(\delta)$; b) Dependence $\eta=f(s)$.

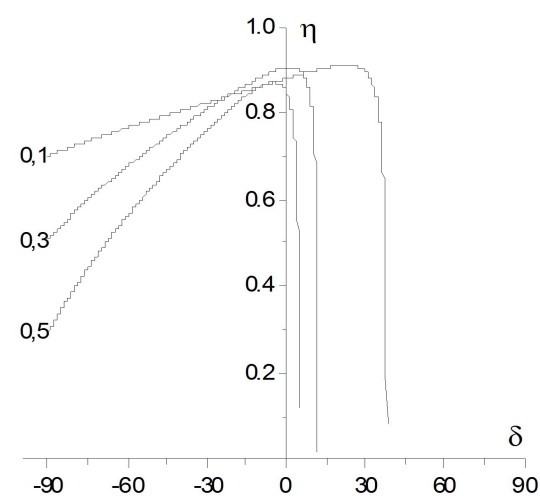

a)

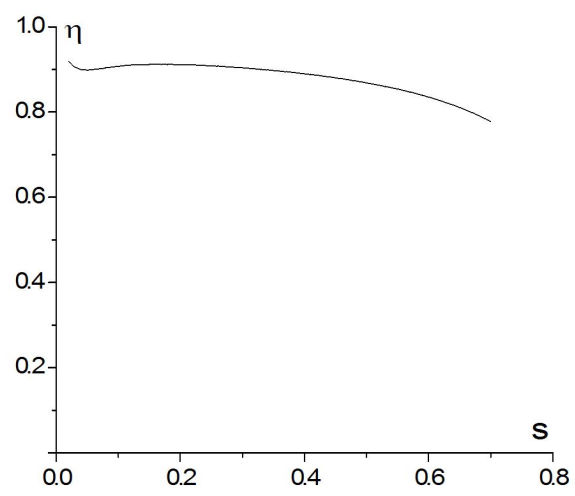

b) 


\section{Conclusion}

Considering the operational characteristics presented in the paper, it can be concluded that the doubly-fed asynchronous generator can be efficiently used in wind power stations, for converting wind kinetic energy into electrical energy. The synchronous working regime, when rotor frequency is set independently, allows stable generator operation in a wide range of speeds, typically within $\pm 30 \%$ of the synchronous speed.

Efficient energy conversion can be achieved in this way, which means that conversion proceeds with maximum exploitation of the wind turbine (for every wind speed there is a specific speed of the wind turbine, and its efficiency is at a maximum).

For obtaining the desired change in the voltage fed to the rotor, semiconductor based energy converters (thyristors, IGBTs, etc.) are included into the rotor circuit. Since the flow of energy in the rotor changes direction in different regimes, energy converters need to enable energy to flow from the grid to the rotor, but also vice versa. At speeds higher than the generator synchronous speed, transformed energy is conveyed to the grid from both the stator and the rotor. The doublyfed asynchronous generator can, therefore, work at an energy higher than the nominal.

Because the power transmitted through the rotor is proportional to the slip, the power of the energy converter is proportional to the regulated speed, typically within $30 \%$ of the nominal wind generator power. This is the main advantage of a doubly-fed asynchronous generator over other wind generators, in which the power of the energy converter corresponds to the full (nominal) power.

Another advantage of a doubly-fed asynchronous generator is the possibility of controlling its reactive power. Modern wind generators can work with the power factor of $\cos \varphi= \pm 0.9$, whereby active and reactive powers it generates can be controlled independently. Naturally, the generated reactive power causes an increase of the energy converter's nominal power.

\section{Apendix}

$p$ - differentiating operator

$\Pi$ - number of pole pairs

$r_{\mathrm{r}}, r_{\mathrm{s}}-$ stator, rotor resistance per phase

$x_{\mathrm{sy}}, x_{\mathrm{r} \gamma}-$ stator, rotor leakage reactance

$x_{\mathrm{m}}$ - magnetizing reactance

$x_{\mathrm{s},} x_{\mathrm{r}}$ - stator, rotor reactance per phase

$L_{\mathrm{s}}, L_{\mathrm{r}}-$ stator, rotor inductance

$L_{\mathrm{m}}-$ magnetizing inductance

$i_{\mathrm{s}}, i_{\mathrm{r}}-$ stator, rotor current

$u_{\mathrm{s}}, u_{\mathrm{r}}$ - stator, rotor voltage

$f_{\mathrm{r}}, f_{\mathrm{s}}-$ stator, rotor frequency

$\Psi_{\mathrm{s}}, \Psi_{\mathrm{r}}$ - stator, rotor magnetic flux

$\delta$ - load angle

$\vartheta$ - the angle between stator and rotor voltage vectors (phasors) $s-\operatorname{slip}$

$n$ - rotor speed

$\omega-$ rotor angular velocity

$\omega_{\mathrm{s}}-$ synchronous angular velocity

$m_{\mathrm{em}}$ - electromagnetic torque

$p_{\mathrm{s}}, p_{\mathrm{r}}$ - stator, rotor active power

$q_{\mathrm{s}}, q_{\mathrm{r}}-$ stator, rotor reactive power

$p_{\text {fvn }}-$ mechanical losses at rated speed

$p_{\text {Fes }}-$ stator core losses

$p_{H k r}-$ hysteresis losses in rotor core (at locked rotor)

$p_{\text {Fkr }}$ - eddy current losses in rotor core

(at locked rotor)

$\eta$ - motor efficiency $\cos \varphi_{\mathrm{s}}, \cos \varphi_{\mathrm{r}}-$ stator, rotor power factor 


\section{Literature}

1. Adjoudj M., Abid M., Aissaoui A. G., Ramdani Y., Bounoua H. (2011): Sliding mode control of a doubly fed induction generator for wind turbines, Rev. Roum. Sci. Techn. - Électrotechn. et Énerg., 56, 1, pp. 15-24, 2011, (available at: http://www.revue.elth.pub.ro/upload/752384MADJOUDJ.pdf)

2. Amaris H., Alonso M. (2011), Coordinated reactive power management in power networks with wind turbines and FACTS devices, Energy Conversion and Managements, Volume 52, Issue 7, July 2011, Pages 2575-2586, (available at: https://doi.org/10.1016/j.enconman.2011.02.012)

3. Boardman G., Zhu J. G., Ha Q.P. (2002), Analysis of the Steady State performance of Doubly Fed Induction Machines, Conference Proceedings, AUPEC, 2002. Melburne, (available at: https://opus.lib.uts.edu.au/bitstream/10453/7257/1/2004003373.pdf).

4. Boardman G., Zhu J.G., Ha Q.P. (2003), Analysis of the steady state performance of doubly fed induction machines, Journal of Electrical and Electronic Engineering, Australia, Vol. 22, No. 3, pp. 211-218, 2003.

5. Elhassan Z., T. Yi, Yan L. (2014), Comparative study of voltage oriented and frequency coordinated control of grid connected doubly fed induction generator, Journal of Renewable and Sustainable Energy vol. 6, Issue 2, pp. 023120 (1-17), April 2014, (available at: https://doi.org/10.1063/1.4873131).

6. Gburčik P., Mastilović V., Vučinić Ž. (2013), Assessment of solar and wind energy resources in Serbia, Journal of Renewable and Sustainable Energy 5, 041822, 1-17, AIP Publishing, Melville, NY, USA, (available at: https://doi. org/10.1063/1.4819504).

7. Gburčik P. et al., (2013), Study of energy potential of Serbia for utilizing solar radiation and wind energy, Project Report EE704-1052A, 2004 (in Serbian). Available per request from the Institute for Multidisciplinary Research, University of Belgrade, Kneza Viseslava 1a, 11030 Belgrade, Serbia (http://www.imsi.rs).

8. Justo J. J., Mwasilu F., Jung J. W. (2014), Doubly fed induction generator wind turbines: A novel integrated protection circuit for low-voltage ride-through strategy, Journal of Renewable and Sustainable Energy vol.6, pp. 053129 (1-15), AIP Publishing, Melville, NY, USA, (available at: https://doi.org/10.1063/1.4819504).

9. Krause P. C., Wasynczuk O., Sudhoff S., Pekarek S. (2013), Analysis of Electric Machinery and Drive Systems, Third Edition, Willy Online Library, ISBN: 9781118524336, DOI: 10.1002/9781118524336.

10.Leonhard W. (2001), Control of Electrical Drives, $3^{\text {rd }}$ ed. Springer-Verlag Berlin Heidelberg, 2001, ISBN 978-3-642-62609-8, ISSN 1612-1287.

11. Mikičić D., Radičević B., Đurišić Ž. (2006), Wind Energy Potential in the World and in Serbia and Montenegro, FACTA UNIVERSITATIS, SER.: ELEC. ENERG. vol. 19, April 2006, 47-61, (available at: http://www.doiserbia.nb.rs/img/doi/0353-3670/2006/035336700601047M.pdf) 
12.Milanović M., Cvijanović D. (2009), Problem and possibilities of economic evaluation of agro - ecological resources, UDC: 504.05/.06:631, Economics of Agriculture, jubilee number (1-88) 2009, Belgrade,

(available at: http://www.ea.bg.ac.rs/images/Arhiva/2009/Tematski\%20broj\%20 -\%202009\%20=\%20Thematic\%20Issue\%20-\%202009.pdf)

13.Milkić Ž., Vukić Đ., Štatkić S. (2014), Rotor Voltage Influence on the Characteristics of a Doubly Fed Induction Machine, Rev. Roum. Sci. Techn.-Electrotechn. et. Energ., 59, 1, pp. 249-258, 2014, (available at: http://revue.elth.pub.ro/viewpdf. php?id=458).

14.Mohammadi J., Afsharnia S., Vaez-Zadeh S. (2014), Efficient fault-ride-through control strategy of DFIG-based wind turbines during the grid faults, Energy Conversion and Managements, Elsevier Ltd vol.78, pp. 88-95, (available at: https:// doi.org/10.1016/j.enconman.2013.10.029).

15.Muller S., Deicke M., de Doncker R. W. (2002), Doubly fed induction generator systems for wind turbines, IEEE Industry Applications Magazine, Volume: 8, Issue: 3, May/Jun 2002 pp. 26-33, DOI: 10.1109/2943.999610.

16.Padrón J. F. M., Lorenzo A. E. F. (2010), Calculating Steady-State Operating Conditions for Doubly-Fed Induction Generator Wind Turbines, IEEE Trans. Power System, Vol. 25, No. 2, pp 922-928. May 2010, DOI: 10.1109/TPWRS.2009.2036853.

17.Petersson A. (2005), Analysis, Modeling and Control of Double - Fed induction Generators for Wind Turbines, Göteborg, Chalmers University of Technology, Göteborg (Sweden), (available at: http://publications.lib.chalmers.se/records/ fulltext/5314/5314.pdf).

18.Quang N. P., Dittrich J. A. (2015), Vector Control of Three-Phase AC Machines: System Development in the Practice (Power Systems), Springer-Verlag Berlin Heidelberg, 2015, ISBN 978-3-662-51803-8, DOI 10.1007/978-3-662-46915-6.

19.Radojević V., Dakić D., Tešić M., Škatarić G., Lukač D. (2009), Renewable sources of energy and agriculture, UDC: 620.91:631, Economics of Agriculture, jubilee number (1-88) 2009, Belgrade,

(available at: http:/www.ea.bg.ac.rs/images/Arhiva/2009/Tematski\%20broj\%20 -\%202009\%20=\%20Thematic\%20Issue\%20-\%202009.pdf)

20.Soens J., Brabandere K., Driesen J., Belmans R. (2003), Doubly Fed Induction Machine: Operating Regions and Dynamic Simulation, EPE 2003, Toulouse, ISBN: 90-75815-07-7.

21.Vukić, Đ., Ercegović, D., Raičević, D., (2006), Application of the Double Fed Induction Generator for Using the Wind Energy, The Montenegrin Academy of Sciences and Arts: Renewable Energy and Future of its Application, Volume 10, pp. 117-124, Podgorica, Montenegro, 2006. 


\title{
KARAKTERISTIKE DVOSTRANO NAPAJANOG ASINHRONOG GENERATORA PRIMENJENOG U VETROELEKTRANAMA ${ }^{6}$
}

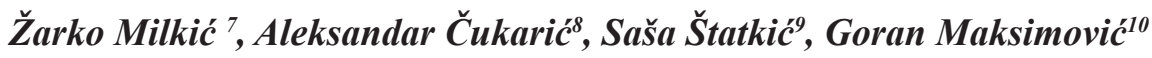

\begin{abstract}
Sažetak
U radu je definisan matematički model asinhronog generator sa dvostranim napajanjem primenom teorije prostornih vektora, u odnosu na referentnu osu vezanu za stator. Izvedeni su izrazi za karakteristične veličine, nacrtane su pogonske karakteristike za moment, aktivne $i$ reaktivne snage, faktor snage i stepen iskorišćenja, na osnovu kojih je izvršena analiza rada u uslovima sa različitom brzinom obrtanja. Na osnovu toga ukazano je na mogućnosti i prednosti primene asinhronog generatora sa dvostranim napajanjem $u$ vetrolektranama, za dobijanje električne energije iz energije vetra.
\end{abstract}

Ključne reči: obnovljivi izvori, vetrogeneratori, održivi razvoj.

6 Rad je deo istraživanja u okviru projekta broj. TR 33016 - Istraživanje, razvoj i primena programa i procedura energetske efikasnosti u elektromotornim pogonima, 2011-2018, finansiran od strane Ministarstva za Obrazovanje, nauku i tehnološki razvoj Republike Srbije. Period projekta: 2011-2018.

7 Vanredni profesor, dr Žarko Milkić, Univerzitet u Prištini, Fakultet tehničkih nauka, Knjaza Miloša 7, 38220 Kosovska Mitrovica, Srbija, Telefon: +38128425 321, E-mail: zarkomilkic@ yahoo.com

8 Vanredni profesor, dr Aleksandar Čukarić, Univerzitet u Prištini, Fakultet tehničkih nauka, Knjaza Miloša 7, 38220 Kosovska Mitrovica, Srbija, Telefon: +381 28425 321, E-mail: acacu58@gmail.com

9 Vanredni profesor, dr Saša Štatkić, Univerzitet u Prištini, Fakultet tehničkih nauka, Knjaza Miloša 7, 38220 Kosovska Mitrovica, Srbija, Telefon:: +381 28425 321, E-mail: sasa.statkic@, pr.ac.rs

10 Vanredni profesor, dr Goran Maksimović, Univerzitet u Prištini, Poljoprivredni fakultet, 38219 Lešak, Srbija, Telefon: +381 2888 261, E-mail: goran.maksimovic@pr.ac.rs

EP 2018 (65) 1 (229-241) 